\title{
The effect of saga milk (Adenantera pavonina, L.) and yogurt starter culture concentration on process of yogurt
}

\author{
1,* Amar, A., ${ }^{1}$ Makosim, S., ${ }^{2}$ Anggraeni, S.T. and ${ }^{2}$ Listilia, N. \\ ${ }^{1}$ Department of Agro-Industrial Technology, Institut Teknologi Indonesia, Jalan Raya Puspiptek Serpong \\ Tangerang Selatan 15320, Banten, Indonesia. \\ ${ }^{2}$ Alumni of Agro-industrial Technology Institut Teknologi Indonesia Jl. Raya Puspiptek Serpong Tangerang \\ Selatan 15320, Banten, Indonesia.
}

\section{Article history:}

Received: 2 January 2021

Received in revised form: 13

March 2021

Accepted: 16 May 2021

Available Online: 5

December 2021

Keywords:

Adenanthera pavonina,

Preference test,

Saga Yogurt

DOI:

https://doi.org/10.26656/fr.2017.5(6).011

\begin{abstract}
This study was aimed to obtain the formulation of saga milk (Adenanthera pavonina, L), with cow's milk and yogurt starter culture concentration which is optimal in the manufacturing of yogurt-based saga milk. The analysis carried out periodically $(0,2,4,6$ hrs after incubation time) was on the change of $\mathrm{pH}$ value, total acids concentration, and lactic acid bacteria (LAB), as well as the preference test of the product only on the finale product. The material used in this study were saga milk, cow's milk and commercial yogurt starter culture consist of Lactobacillus acidophilus, Bifidobacterium, and Streptococcus thermophilus. This experiment design was random block design, factorial pattern $(3 \times 3)$. Factor a is the concentration of starter culture consisting of three levels by 3\% (a1), 4\% (a2), 5\% (a3), and formulation of saga milk compared to cow's milk (b) with the ratio of 40:60 (b1), 50:50 (b2), 60:40 (b3), this experiment replicated three times. The result showed that with more cow's milk and yogurt starter culture concentration, the $\mathrm{pH}$ of yogurt decreased, which was accompanied by increased acidity. Although LAB in products with a starter culture $3 \%$ and $4 \%$ were slightly lower than in products with $5 \%$ starter but not significant $(\mathrm{p}=0.05)$. The addition of the starter culture increased the acceptance of panelists. The addition of saga milk, up to $60 \%$, provides results that can still be accepted with the addition of coco-pandan syrup by panelists. The preferred saga yogurt has a white color like cow's milk, with sufficient viscosity and an acceptable taste
\end{abstract}

\section{Introduction}

Yogurt is a processed product obtained from a fermented dairy product that has several health benefits and is usually mixed with a yogurt starter culture consisting of thermophilic lactic acid bacteria Stretptococcus thermophilus and Lactobacillus bulgaricus ssp. bulgaricus (Aswal et al., 2012). According to Winarno et al. (2003), fresh milk contains various microbes which produce various kinds of acids and flavors. However, commercial yogurt traditionally uses two popular types of lactic acid bacteria, namely $S$. thermophilus and L. bulgaricus.

According to the Data Center for Agricultural Information Systems (Pusat Data dan Sistem Informasi Pertanian, 2016), the increase in the availability of local cow's milk is usually accompanied by an increase in imported cow milk commodities. Another source of protein having a protein value that is almost the same as cow's milk is from some types of beans, such as soybeans and saga beans. Soybean protein values per $100 \mathrm{~g}$ are $34.9 \%$, while saga bean seeds per $100 \mathrm{~g}$ are $30.6 \%$, meaning that the protein content in both types of beans can be an alternative source of vegetable protein.

The import of soybeans in Indonesia from 2015 until 2020 is predicted to reach 3,398008 tons (Aimon and Sutranto, 2014). Adenanthera pavonina is a plant that is viable to be developed in tropical countries. It can produce 100-150 kg per tree per year and can be harvested throughout the year (Suita, 2013). Saga bean plant (Adenanthera pavonina, L.) is a perennial plant that has the advantages as follows, it grows well in various types of soils including low $\mathrm{pH}$ soil, and it is a large tree suitable for tropical wetland areas such as Indonesia and needs easy maintenance (Amar, 2017).

Saga trees have many benefits. Adenanthera pavonina, L. bark extract, with various solvents can 
inhibit the growth of Gram-positive and Gram-negative bacteria including Pseudomonas aeruginosa, Bacillus subtilis, Enterobacter aerogenes, Staphylococcus epidermidis, and Salmonella enterica serova Typhimurium (Hussein et al., 2011). Other researchers used the dry bark of A. pavonina, L. extract and have found it very useful. A dried and ground bark of $A$. pavonina, L. extract with methanol is able to have antiinflammatory activity in animal experiments with mice (Arzumand et al., 2018). Another research reported that the Adenanthera pavonine seed aqueous extract was able to treat diabetes in mice and associated lipid disorders (Pandhare et al., 2012). The use of saga seeds is not only for tempeh (Amar, 2020) but it can also be extracted to produce heteropolysaccharide galactomannan as biopolymers (Melo et al., 2018). The raw material of yogurt is always identified with cow's milk. Actually, vegetable milk such as soy milk or saga milk can also be produced into yogurt. The use of saga seeds as milk has been reported by another researcher who also used an extract of sesame seeds to give a brighter colour to saga milk (Yenrina et al., 2014). Tempeh of Saga with certain starter cultures has the potential to produce long-chain fatty acids that are good for health (Amar, 2020). Another research reported that saga seeds can reduce cholesterol in quail eggs (Hartono et al., 2012).

New other research about the use of saga seeds has been reported that saga milk has the potential to improve neurological diseases. This is evidenced by a decrease in the activity of Cholinesterase in the liver, heart and kidneys of mice as experimental animals. It is assumed that saga milk can facilitate the transfer of ions so they can penetrate the cell membrane (Afolabi et al., 2018). Saga milk can also be made into fresh cheese, like fresh cheese made from cow's milk (Amar et al., 2017).

The objective of this study was to obtain the optimal formula of saga milk and concentration of yogurt starter culture to produce yogurt which can be accepted organoleptically by the panellists. Adenanthera pavonina, L. as one of the tropical country's biodiversity assets must be optimized for the welfare of humanity.

\section{Materials and methods}

\subsection{Procedures}

The ingredients used were the saga bean seeds (Adhenantera pavonina, L.), originating from the campus of the Institut Teknologi Indonesia, Serpong, fresh plain pasteurized milk, skim milk powder, plain yogurt starter culture (Yummy fresh product), that was purchased at PT. Yummy Food Utama, Jakarta. Other ingredients were neutral aquadest, alcohol 70\%, PP indicator $1 \%, \quad \mathrm{NaOH} \quad 0.1 \mathrm{~N} \quad$ (Merck), MRS-Agar
(CM0361-Oxoid) and sodium bicarbonate $\left(\mathrm{NaHCO}_{3}\right)$, Merck. The research was conducted at the Fermentation Laboratory and Microbiology Laboratory, AgroIndustrial Technology Study Program, Institut Teknologi Indonesia, Serpong, Tangerang Selatan, Banten. The research was conducted in a block randomized design consisting of two factors, namely factor A was the concentration of commercial yogurt culture starter, factor B was milk formulation, factor A consisted of concentrations as follows: $\mathrm{a} 1=3 \%$, a $2=4 \%$, and $\mathrm{a} 3=$ $5 \%$. Factor B consisted of a ratio between saga milk to cow's milk as follows: $b 1=(40: 60), b 2=(50: 50), b 3=$ (60:40), and the parameters measured were $\mathrm{pH}$ of the product (using Hanna Instrument, and before using, the instrument was calibrated with buffer solution), total acid calculated as lactic acid (SNI 01-2981-2006 yoghurt in Badan Standar Nasional, 2009) and total Lactic acid bacteria (LAB) by Jannah et al. (2014), during the fermentation process. The Preference Test was carried out using the Fliedner and Wilhelmi (1993) method.

\subsection{Saga milk process}

Saga bean seeds were soaked in water for $24 \mathrm{hrs}$ and then boiled for 60 mins. Then, peeled to separate the skin and washed thoroughly. After that, the endosperm of the saga bean seeds was washed and followed by boiling for 15 mins. Then, milled with $80^{\circ} \mathrm{C}$ hot water for 2 mins followed by filtering and separating the pulp. The separated pulp was milled again for $30 \mathrm{~s}$. After that, the filtration results were added with $0.5 \% \mathrm{NaHCO}_{3}$ and pasteurized at $80^{\circ} \mathrm{C}$ for 10 mins. Saga milk was then ready for use.

2.3 Saga yogurt process, $p H$ value, total titrated acids, and total lactic acid bacteria analysis

The yogurt process was conducted as follows 1800 $\mathrm{mL}$ prepared saga milk added to sodium hydrogen carbonate as much as $0.5 \%$ and then pasteurized at $80^{\circ} \mathrm{C}$ for 10 mins then cooled to a temperature of $40^{\circ} \mathrm{C}$, parallel with that, also pasteurized $1800 \mathrm{~mL}$ of cow's milk which has been added with skim milk powder as much as $3 \%$ at a temperature of $95^{\circ} \mathrm{C}$ and then cooled to a temperature of $40^{\circ} \mathrm{C}$. The formulations were made as followed: $400 \mathrm{~mL}$ saga milk $+800 \mathrm{~mL}$ cow's milk mixed homogeneously (b1) then divided into 12 sterilized glass bottles and inoculated each 4 bottles consecutively with $3 \%$ (a1), 4\% (a2), and 5\% (a3) commercial yoghurt starter cultures, $600 \mathrm{~mL}$ saga milk $+600 \mathrm{~mL}$ cow's milk mixed homogeneously (b2) then divided into 12 glass bottles and inoculated each 4 bottles consecutively with $3 \%, 4 \%$, and $5 \%$ commercial yoghurt starter culture, 800 $\mathrm{mL}$ saga milk $+400 \mathrm{~mL}$ cow's milk mixed homogeneously (b3) then divided into 12 glass bottles and inoculated 4 bottles respectively with $3 \%, 4 \%$ and 
$5 \%$ commercial yoghurt starter culture. All preparations were fermented in an incubator at $44.1^{\circ} \mathrm{C}$, and periodically at $0 \mathrm{hr}(\mathrm{c} 1) ; 2 \mathrm{hrs} \mathrm{(c2),} 4 \mathrm{hrs} \mathrm{(c3)}$ and $6 \mathrm{hrs}$ (c4) after incubation was analysed for $\mathrm{pH}$ and total acid, as well as total lactic acid bacteria. These experiments were repeated three times. Data were analysed using Variance analysis and further test was conducted with Duncan's New Multiple Range Test (DMRT) at the level of $5 \%$.

The measurement of the $\mathrm{pH}$ value of the product, 50 $\mathrm{mL}$ of the sample was prepared and filled in a beaker glass and the tip of the electrode was inserted into the sample as deep as $5 \mathrm{~cm}$. The measurement result was read as the $\mathrm{pH}$ value. The determination of the total titrated acids (is calculated as the total lactic acids) in the sample was done by titration using $0.1 \mathrm{~N} \mathrm{NaOH}$ according to the Standard Nasional Indonesia (SNI 012981-2006 Yoghurt, 2009). Meanwhile to determine the total growth of LAB in the product using the Pour Plate method (Jannah et al., 2014) means that the sample was diluted until the determined concentration and then was cultured in the MRS-Agar media and incubated at $40^{\circ} \mathrm{C}$. Then the sample was calculated for the total LAB.

\subsection{Preference test}

The test used the Fliedner and Wilhelmi method (1993). The category of panellists used was not properly trained panelist, with ages ranging between 18-27 years. Panelists were asked to give an evaluation of the yogurt product, which was served by adding coco-pandan syrup, on a scale of 1 to 9 for the performance, texture, aroma and taste attributes. The range of scores given was 1-9, starting from like exceedingly (9), like very much (8), like (7), rather like (6), neutral (5), rather dislike (4), dislike (3), dislike very much (2) and dislike exceedingly (1). [Whether or not a product was accepted was subject to the following conditions: The score the panellists must give is 6 or above. When the score was 6 or above, then they are included in the calculation for acceptance. However, if the assessment was below 6 then it is not counted in the calculation for acceptance. If the percentage of panellists that give the above score is between $0-65 \%$, it means not accepted; $66-72 \%$ it means far from accepted or a very little accepted (weighty complaints, require more improvements on some sensory parameters); $73-79 \%$ it means almost accepted (complaints given, require more improvements on one or two sensory parameters); $80-86 \%$ it means accepted (not free of complaints, require improvements one of sensory parameters); $87-93 \%$ it means more than accepted (almost free of complaints, no improvement necessary); $94-100 \%$ it means exceptionally accepted (free from complaints, no improvement necessary)

\section{Results and discussion}

The pasteurization of cow's milk was carried out at a temperature of $95^{\circ} \mathrm{C}$, which is higher than the pasteurization temperature of saga milk. This must be done so that the lactoglobulin and lactoalbumin present in cow's milk are completely denaturized. The denaturized condition causes the lactoglobulin and lactoalbumin to have no capability anymore to disturb the stability of yogurt gel. Meanwhile, the pasteurization saga milk only aims to kill pathogenic microorganisms. The preliminary research that has been done (data unpublished) using the saga milk formula for yogurt shows that if the concentration of saga milk is more than $60 \%$, the flavour of the resulting yogurt has a very sharp beany flavour and the gel formed was unstable. Therefore, only three milk formulas were chosen in this main research. Previous studies showed that soymilk fermented with Lactobacillus plantarum bacteria in the process of producing yogurt was able to improve the dysregulation of cholesterol metabolism in rats fed with a high cholesterol diet (Kim et al., 2014). The concentration of starter culture used in saga yogurt was only $3 \%, 4 \%$ and $5 \%$. This was determined because the culture used was commercial plain yogurt. It is therefore believed that with 3 to $5 \%$ commercial yogurt culture starters are able to form normal yogurt. Even the 4th starter culture $(\mathrm{F} 4)$ generation stored in the refrigerator for 25 days still has a 7-8 Log CFU/mL of LAB viability and is still suitable for use as a starter culture (Fitrianingrum et al., 2016). Many researchers state that the culture can actually start at $1 \%$. This is possible if the culture is freshly developed. This research used commercial yogurt starter culture, previous study used $L$. acidophilus strain SBT 202 culture still has 100\% viability for 7 days stored at $4^{\circ} \mathrm{C}(\mathrm{Ng}$ et al., 2011). However, in the same type of culture with a different strain of $L$. acidophilus strain NCFM at the same storage condition the viability is only $10 \%(\mathrm{Ng}$ et al., 2011). The yogurt culture starter used in our research was a mixed culture containing $S$. thermophilus, L. acidophilus and Bifidobacterium bifidum. The last two species include probiotic bacteria. The probiotic microorganism is able to produce more acetaldehyde than the usual yogurt culture, thereby reducing the aroma of beany flavour in soy yogurt (Donkor et al., 2007). According to Chang et al., 2010 the mixed culture for soy yogurt produced good quality characteristics. It is expected that the saga milkbased yogurt also produces a reduced beany flavour.

\section{$3.1 \mathrm{pH}$ Value}

Fermentation occurs as indicated by the change in $\mathrm{pH}$ value of the yogurt, its acidity level. It can be seen in Table 1 that the initial milk formulation has an average $\mathrm{pH}$ value of 6.97 but after incubation for $6 \mathrm{hrs}$ the final 
Table 1. Effect of incubation time on total bacteria lactic acid $\mathrm{pH}$ value and total titrated acid of saga yogurt

\begin{tabular}{cccc}
\hline $\begin{array}{c}\text { Incubation time } \\
\text { (hours) }\end{array}$ & $\begin{array}{c}\text { Average of total lactic acid } \\
\text { bacteria (Log CFU/mL) }\end{array}$ & $\begin{array}{c}\text { Average of pH value of } \\
\text { saga yoghurt }\end{array}$ & $\begin{array}{c}\text { Average of total titrated } \\
\text { acid (\%) }\end{array}$ \\
\hline 6 & $5.48 \pm 0.24^{\mathrm{a}}$ & $4.69 \pm 0.05^{\mathrm{c}}$ & $0.21 \pm 0.03^{\mathrm{a}}$ \\
4 & $4.39 \pm 0.41^{\mathrm{b}}$ & $5.00 \pm 0.16^{\mathrm{c}}$ & $0.15 \pm 0.03^{\mathrm{b}}$ \\
2 & $4.05 \pm 0.70^{\mathrm{bc}}$ & $6.03 \pm 0.32^{\mathrm{b}}$ & $0.08 \pm 0.01^{\mathrm{c}}$ \\
0 & $3.23 \pm 1.05^{\mathrm{c}}$ & $6.94 \pm 0.28^{\mathrm{a}}$ & $0.04 \pm 0.01^{\mathrm{d}}$ \\
\hline
\end{tabular}

Values are presented as mean \pm standard deviation $(n=9)$. Values with different superscript within the column are significantly different $(\mathrm{p} \leq 0.05)$.

$\mathrm{pH}$ value dropped to 4.69 , which was an ideal $\mathrm{pH}$ value for yoghurt. The research was set up until the measured $\mathrm{pH}$ reached 4.6-4.8, and on observation $6 \mathrm{hrs}$ after incubation, the $\mathrm{pH}$ value had reached the $\mathrm{pH}$ which was usually owned by commercial yogurt. Therefore, the observation was stopped and the product was immediately stored in the refrigerator at $8-10^{\circ} \mathrm{C}$ to develop its flavour and the next day the panellist's preference test was carried out. Incubation time significantly affects the $\mathrm{pH}$ value of yogurt, this is due to the increasing growth of lactic acid bacteria. It was also observed that the longer the incubation time up to $6 \mathrm{hrs}$, the $\mathrm{pH}$ value is significantly reduced, and the average total titrated acids reached up to $0.21 \%$. This condition indicates that an increase in the length of the incubation time, the number and the activity of microbes will increase the lactose which is converted into lactic acid, causing a decrease in $\mathrm{pH}$. This is in line with Wardhani's research (2015) which states that the longer duration of fermentation and the more the starter concentration will be accompanied by a decrease in $\mathrm{pH}$ value. However, it was reported by Wardhani et al. (2015) that the incubation time reached $15 \mathrm{hrs} \mathrm{pH}$ value of Corn yoghurt only has a $\mathrm{pH}$ of 4.0 .

However, based on our observations in this study, the increase in the concentration of yoghurt starter cultures, the data is shown in Table 2, and differences in saga milk formulations (Table 3 ) did not significantly affect the $\mathrm{pH}$ value of yogurt. The addition of saga milk was able to slow down the $\mathrm{pH}$ decrease even though it was not significant. This was because saga milk has a lactose content which is much less compared to cow's milk. Another previous study showed that the addition of date palm extract can accelerate the decrease in $\mathrm{pH}$ of yogurt drinks (Hartati et al., 2012).

\subsection{Total titrated acid value as lactic acid}

Decreasing $\mathrm{pH}$ value and increasing concentration of lactic acid in yogurt saga during fermentation is caused by the lactose in cow's milk. Lactose is hydrolysed by LAB in yogurt culture (L. acidophilus, Bifidobacterium and $S$. thermophilus). The capability of LAB to use lactose in this fermentation process can be explained as follows: lactose will be hydrolysed by the permease enzyme, which is then converted by lactase to galactose and glucose, and the glucose formed will then be metabolized to lactic acid.

Table 2 was shown that the addition of yogurt culture starter concentration tends to increase the concentration of lactic acid, although not significant between $3 \%$ and $4 \%$ yogurt starter culture. However, when compared between $3 \%$ and $5 \%$, there is a significant difference, and between 4 and 5\% was also not significant, therefore it is chosen for the use of $4 \%$ yogurt starter culture in manufacturing of saga yogurt. However, it all depends also on the panellists' preference test. Total titrated acid as lactic acid in the saga yogurt product reached up to $0.21 \pm 0.03 \%$, relatively smaller compared to other yogurts in several studies. But it is still comparable to soy yogurt, including saga yogurt derived from saga milk mixed with 40-60\% cow's milk. Previous soy yogurt studies have total lactic acid ranging from 0.13-0.40 (without the addition of cow's milk) while cow's milk yogurt has higher lactic acid content with a range between 0.08-0.43\% (Horáčková et al., 2015). In another study, yogurt derived from cow's milk added with tomato juice extract has higher lactic acid than the control sample in the range of $0.48-0.61 \%$. This is relatively high due to the high sugar content in tomato juice, which can stimulate the growth of LAB. (Savitry et al., 2017). The addition of the incubation time was

Table 2. Effect of addition of starter on lactic acid bacteria, $\mathrm{pH}$ value and total titrated acids of saga yogurt

\begin{tabular}{cccc}
\hline $\begin{array}{c}\text { Concentration of yogurt } \\
\text { starter culture (\%) }\end{array}$ & $\begin{array}{c}\text { Average of total lactic acid } \\
\text { bacteria (Log CFU/mL) }\end{array}$ & $\begin{array}{c}\text { Average of pH value of } \\
\text { saga yoghurt }\end{array}$ & $\begin{array}{c}\text { Average of total titrated } \\
\text { acid (\%) }\end{array}$ \\
\hline 5 & $4.80 \pm 0.55^{\mathrm{a}}$ & $5.78 \pm 0.95^{\mathrm{a}}$ & $0.13 \pm 0.07^{\mathrm{a}}$ \\
4 & $4.24 \pm 1.03^{\mathrm{a}}$ & $5.59 \pm 0.95^{\mathrm{a}}$ & $0.13 \pm 0.07^{\mathrm{a}}$ \\
3 & $3.82 \pm 1.25^{\mathrm{a}}$ & $5.62 \pm 0.95^{\mathrm{a}}$ & $0.11 \pm 0.07^{\mathrm{b}}$ \\
\hline
\end{tabular}

Values are presented as mean \pm standard deviation $(n=9)$. Values with different superscript within the column are significantly different $(\mathrm{p} \leq 0.05)$ 
Table 3. Effect of formulation of saga milk on lactic acid bacteria, $\mathrm{pH}$ value, and total titrated acid of saga yogurt

\begin{tabular}{cccc}
\hline $\begin{array}{c}\text { Formulation of saga } \\
\text { milk: cow milk }\end{array}$ & $\begin{array}{c}\text { Average of total LAB } \\
(\text { Log CFU/mL) }\end{array}$ & $\begin{array}{c}\text { Average of pH value of } \\
\text { saga yoghurt }\end{array}$ & $\begin{array}{c}\text { Average of total titrated } \\
\text { acid (\%) }\end{array}$ \\
\hline $40: 60$ & $4.36 \pm 0.56^{\mathrm{a}}$ & $5.66 \pm 0.94^{\mathrm{a}}$ & $0.13 \pm 0.08^{\mathrm{a}}$ \\
$50: 50$ & $4.23 \pm 0.41^{\mathrm{a}}$ & $5.66 \pm 0.94^{\mathrm{a}}$ & $0.12 \pm 0.07^{\mathrm{ab}}$ \\
$60: 40$ & $4.25 \pm 0.39^{\mathrm{a}}$ & $5.84 \pm 1.04^{\mathrm{a}}$ & $0.11 \pm 0.07^{\mathrm{ab}}$ \\
\hline
\end{tabular}

Values are presented as mean \pm standard deviation $(n=9)$. Values with different superscript within the column are significantly different $(\mathrm{p} \leq 0.05)$.

able to increase the total titrated acid as shown in Table 1 , and the addition of saga milk up to $50 \%$ was able to increase the total titrated acid significantly, the data is shown in Table 3.

\subsection{Total lactic acid bacteria}

In Table 1, it is shown that the total LAB in saga yogurt increases with increasing incubation time. It is easy to understand that because $\mathrm{LAB}$ grows and develops with incubation time. However, the number of LAB cells produced was relatively low 6 hours after fermentation, only reaching $5.48 \pm 0.24 \log \mathrm{CFU} / \mathrm{mL}$. It might be due to saga milk media being a new media for yoghurt starter culture, so that adaptation is needed for cell proliferation. However, the presence of lactose from cow's milk provides a relatively fast adaptation for the active metabolic processes of microorganisms. Thus, within $6 \mathrm{hrs}$ it reaches the $\mathrm{pH}$ that is usually owned by commercial yogurt derived from cow's milk.

In another study using soy milk in the yogurt process, at the age of $16 \mathrm{hrs,}$ the Lactobacillus bulgaricus culture was able to reach $6.38 \mathrm{Log} \mathrm{CFU} / \mathrm{mL}$ (Horáčková et al., 2015). Furthermore, another study with yogurt based on cow's milk and added with tomato juice at the age of $4 \mathrm{hrs}$ of fermentation reached 6.8-8.0 Log CFU/mL (Safitry et al., 2015). The low number of cells of LAB in saga yogurt is in accordance with the total acid in Table 2 also in Table 3. The question arises whether there is indeed a compound in saga milk that inhibits the growth of LAB. A previous study by Radziah et al. (2011) proved that saga seed oil has antibacterial properties. The increase of the concentration of yogurt starter culture also seems not to be significant to increase the number of LAB cells.

Increasing the concentration of starter cultures did not significantly increase the total LAB (Table 2). Another study by Jumah et al. (2001), reported that starter culture level had a definite effect on yogurt viscosity during the gelation process. Likewise, the addition of saga milk in the formula up to $60 \%$ does not affect the total LAB (Table 3)

\subsection{Preference test}

The addition of saga milk in milk formula for manufacturing yogurt has an influence on the preference test. With increasing concentrations of saga milk, the panellist assessment of the colour, texture, aroma and taste of yogurt decreases. The taste of saga yogurt is similar to soy yogurt. Research with soy yogurt fermented with Bifidobacterium bifidum shows it can reduce the total level of plasma cholesterol in the rat (Champagne et al., 2009). Other researchers in their experiment on rats suggest that soy yogurt can prevent hepatic lipid accumulation (Kitawaki et al., 2009). Therefore, health function must be highlighted in comparison to the taste of the product. Because the taste can be accustomed.

Table 4 illustrates the overall panellist acceptance of saga yogurt. Variations in acceptance for yogurt colour ranged from low, only $37 \%$ of panelist who liked the saga yogurt, to $100 \%$ of panellists who liked this product colour. The addition of fruit flavour gives a positive effect on the Preference Test, whereby strawberry is the most favoured by panellists compared to other fruit flavours (Osundahunsi et al., 2007). Therefore, the Preference Test in this research used Cocopandan syrup to increase the panellist's acceptability. Other research about soy yogurt shows that the use of orange fruit flavour or banana flavour also gives a positive effect on acceptance by panellists (Raeisi et al., 2017). All saga yogurt inoculated with 5\% yogurt starter culture were accepted by the panellists. This is indicated by $85 \%$ of the panellists choosing "likes" of the hedonic scale. On the contrary, for saga yogurt with either $3 \%$ or $4 \%$ yogurt starter culture, only one formula was almost accepted by the panellists.

All panellists noted that the yogurt with the addition of $5 \%$ starter culture had a white colour, like cow's milk, with moderate viscosity, and was less acidic and even had a slight beany flavour. Most of the panellists like that the texture of the yogurt saga is slightly viscous than usual, is this why the panellists like the texture still need to be further explored. The appearance of moderate viscosity of saga yogurt texture may also be caused by galactomannan biopolymer compounds that have saga seeds. It might be assumed, the presence of polysaccharides in Saga milk stimulates the formation of a thicker gel. This is in line with the research by Jumah et al. (2001) which showed that polysaccharides and 
Table 4. Acceptance percentage of saga yogurt

\begin{tabular}{cccccccc}
\hline & Treatment & \multicolumn{7}{c}{ Acceptance of panelist (\%) } \\
\hline $\begin{array}{c}\text { Starter culture } \\
\text { concentration }\end{array}$ & $\begin{array}{c}\text { Milk formula } \\
\text { Saga milk: cow's milk }\end{array}$ & $\begin{array}{c}\text { Appearance/ } \\
\text { colour }\end{array}$ & Texture & Aroma & Taste & $\begin{array}{c}\text { Overall } \\
\text { Acceptance }\end{array}$ & $\begin{array}{c}\text { Average } \\
\text { acceptance }\end{array}$ \\
\hline \multirow{3}{*}{$3 \%$} & $40: 60$ & 67 & 80 & 50 & 50 & NA & \\
& $50: 50$ & 73 & 73 & 67 & 70 & 283 & $70.8^{\mathrm{e}}$ \\
& $60: 40$ & 67 & 67 & 67 & 57 & NA & $77.5^{\text {d }}$ \\
$4 \%$ & $40: 60$ & 73 & 77 & 83 & 77 & 310 & \\
& $50: 50$ & 37 & 67 & 50 & 57 & NA & \\
$5 \%$ & $60: 40$ & 40 & 47 & 60 & 33 & NA & $85^{\text {c }}$ \\
& $40: 60$ & 90 & 90 & 73 & 87 & 340 & $95^{\text {a }}$ \\
& $50: 50$ & 100 & 87 & 97 & 97 & 381 & $86^{\mathrm{b}}$ \\
\hline
\end{tabular}

NA: Not accepted.

Level of acceptance are categorized with the following:

${ }^{a}$ free from complaints, no improvement necessary;

balmost free of complaints, no improvement necessary;

c not free of complaints, require improvements one of sensory parameters;

${ }^{d}$ complaints given, require more improvements one or two sensory parameters;

${ }^{\mathrm{e}}$ weighty complaints, require more improvements on some sensory parameters.

proteins collaborate in forming a solid gel. Heteropolysaccharide in saga seeds have been isolated by Melo et al. (2018) and it is nontoxic. Thus, yoghurt saga is also expected to be non-toxic or safe for consumption and even has good functional properties, for example, saga milk fat which contains lignoceric acid.

Preference test plays an important role in product acceptance which includes appearance/color, texture, aroma and taste. The use of a 5\% yogurt starter culture in this process of saga yogurt was favored by panellists. Saga yogurt with a formulation of 50:50 (saga milk: cow's milk) and inoculated yogurt starter culture of 5\% tended to be favoured by panellists because of the white colour like cow's milk, with sufficient viscosity in texture and an acceptable taste, and flavour.

\section{Conclusion}

The addition of the starter culture up to $5 \%$ increased the acceptance of panellists. The addition of saga milk, up to $60 \%$, provides results that can still be accepted by panellists. The preferred saga yogurt has a white colour like cow's milk, with sufficient viscosity and an acceptable taste.

\section{Acknowledgement}

Thanks to Institut Teknologi Indonesia Serpong Tangerang Selatan for financial support during the research through the contract number: 081/KP/LPKTITI/VI/2019.

\section{References}

Afolabi, I.S., Nwachukwu, I.C., Ezeoke, C.S., Woke,
R.C., Adegbite, O.C., Olawole, T.D., and Martins, O.C. (2018). Production of a new plant-based milk from Adenanthera pavonina seed and evaluation of Its nutritional and health benefits. Frontiers in Nutrition, $\quad 5, \quad 9 . \quad \mathrm{https} / / /$ doi.org/10.3389/ fnut.2018.00009

Aimon, H. and Sutranto, A. (2014). Prospek konsumsi dan impor kedelai di Indonesia Tahun 2015-2020. Jurnal Kajian Eknomi, 3(5), 1-13.

Amar, A. (2017). Saga Pohon Sebagai Pendamping Tanaman Kedelai Terealisasikah? In Santosa, U., Giyatmi, Pambayun, R., Rahayu, W.P. and Michwan, A. (Eds.). Impian Pangan Indonesia, p. 70 -73. Yogyakarta, Indonesia: Interlude. [In Bahasa Indonesia].

Amar, A. (2020). Tempe and Cheese Based Saga (Adenanthera pavonina, L.) as a Feasible and Functional Food. In Mahendradatta, M., Rahayu, W.P., Santosa, U., Giyatmi., Ardiansyah., Fibri, D.L.N., Kusnandar, F. and Witono, Y. (Eds.). Current Issues of Food in Indonesia, p. 100-103. Yogyakarta, Indonesia: Interlude.

Amar, A., Makosim, S. and Marwati. (2017). Karakteristik keju lunak saga (Adenanthera pavonina, Linn.) dengan berbagai kemasan dan waktu simpan yang berbeda. Jurnal IPTEK, 1(2), 99106. https://doi.org/10.31543/jii.v1i2.128 [In Bahasa Indonesia].

Arzumand, A., Arifuzzaman, M., Ghosh, C.K., Hashem, M.D.A., Ahmad, M.U., Bachar, M.C., Nahar, L. and Sarker, S.D. (2010). Anti-inflammatory activity of Adenanthera pavonina L., Fabaceae, in experimental animals. Brazilian Journal of Pharmacognosy, 20 (6), 929-932. https://doi.org/10.1590/S0102- 


\section{X2010005000039}

Aswal, P., Shukla, A. and Priyadarshi, S. (2012). Yogurt: Preparation, characteristics and recent advancements. Cibtech Journal of Bio-Protocols, 1 (2), 32-44.

Badan Standardisasi Nasional. (2009). SNI 01- 29812006 Yoghurt. Jakarta, Indonesia: Badan Standardisasi Nasional.

Champagne, C.P., Green-Johnson, J., Raymond, Y., Barrette, J. and Buckley, N. (2009). Selection of probiotic bacteria for the fermentation of a soy beverage in combination with Streptococcus thermophilus, Food Research International, 42(5-6), 612-621. https://doi.org/10.1016/ j.foodres.2008.12.018

Chang, S.Y., Kim, D.H. and Han, M.J. (2010). Physicochemical and sensory characteristics of soy yogurt fermented with Bifidobacterium breve K-110, Streptococcus thermophilus 3781, or Lactobacillus acidophilus Q509011. Food Science Biotechnology, 19(1), 107-113. https://doi.org/10.1007/s10068-0100015-0

Donkor, O.N, Henriksson, A., Vasiljevic, T. and Shah, N.P. (2007). Rheological properties and sensory characteristics of set-type soy yogurt. Journal of Agricultural Food Chemistry, 55, 9868-9876. https://doi.org/10.1021/jf071050r

Ng, E.W., Yeung, M. and Tong, P.S. (2011). Effect of yogurt starter on the survival of Lactobacillus acidophilus. International Journal of Food Microbiology, 145(1), 169-175. https:// doi.org/10.1016/j.ijfoodmicro.2010.12.006

Fitrianingrum, F., Priadi, G. and Afiati, F. (2016). The quality of the yogurt starter is dried during the refrigerator temperature storage. Seminar Nasional Masyarakat Biodiversitas, Bogor, 2016. Bogor, Indonesia: Masyarakat Biodiversitas Indonesia.

Fliedner, I. and Wilhelmi. (1993). Grudlagen und Pruefverfahren der Lebensmittelsensorik. Hamburg, Germany: Behr's Verlag.

Hartati, A.I., Pramono, B. and Legowo, A.W. (2012). Lactose and reduction sugar concentration, $\mathrm{pH}$ and the sourness date flavored yogurt drink as probiotic beverage. Journal of Applied Food Technology, 1, 13.

Hartono, A.K., Liem, O.P.P., Putri, B.E. and Hartini, S. (2012). Asam lignoserat biji saga (Adenanthera pavonia, L.) sebagai penurun kholesterol pada telur puyuh. Prosiding Seminar Nasional Sains dan Pendidikan Sains VII, Salatiga, 2012. Salatiga, Universitas Kristen Satya Wacana. [In Bahasa Indonesia].
Horáčková, S., Mühlhansová, A., Sluková, A., Schulzová, V. and Plocková, M., (2015). Fermentation of soymilk by yogurt and Bifidobacteria strains. Czech Journal of Food Science, 33(4), 313-319. https:// doi.org/10.17221/115/2015-CJFS

Jannah, A.M., Legowo, A.M., Pramono, Y.B., Al-Baari, A.M. and Abduh, S.B.M. (2014). Total bakteri asam laktat, $\mathrm{pH}$, keasaman, citarasa dan kesukaan yogurt drink dengan penambahan ekstrak buah belimbing . Junal Aplikasi Teknologi Pangan, 3(2), 7-11.

Jumah, R.Y., Abu-Jdayil, B. and Shaker, R.R. (2001). Effect of type and level of starter culture on the rheological properties of set yogurt during gelation process. International Journal of Food Properties, 4 (3), 531-544. https://doi.org/10.1081/JFP100108654

Kim, Y., Yoon, S., Le, S.B., Han, H.W., Oh, H., Lee, W.J. and Lee, S.M., (2014). Fermentation of soy milk via Lactobacillus plantarum improves dysregulated lipid metabolism in rats on a high cholesterol diet. Plos One, 9(2), e88231. https:// doi.org/10.1371/journal.pone.0088231

Kitawaki, R., Nishimura, Y., Takagi, N., Iwasaki, M., Tsuzuki, K. and Fukuda, M. (2009). Effect of Lactobacillus fermented soy milk and soy yogurt on hepatic lipid accumulation in rats fed a cholesterolfree diet. Bioscience, Biotechnology, Biochemistry, 73(7), 1484-1488. https://doi.org/10.1271/bbb.80753

Melo, R.C., Geronco, M.S., Sousa, R.W.R., Ramos, L.P.S., Araujo, F.P., Ribeiro, A.B., Ferreira, P.M.P., Osajima, J.A. and Costa, M.P. (2018). Biopolymer from Adenanthera pavonina L. Seeds: Characterization, Photostability, Antioxidant Activity. International Journal of Polymer Science, 2018, $1385830 . \quad \mathrm{https} / /$ doi.org/10.1155/2018/1385830

Osundahunsi, O.F., Amosu, D. and Ifesan, B.O.T. (2007). Quality evaluation and acceptability of soyyogurt with different colours and fruit flavours. American Journal of Food Technology, 2(4), 273280. https://doi.org/10.3923/ajft.2007.273.280

Pandhare, R.B., Sangameswaran, B., Mohite, P.B. and Khanage, S.B (2012). Anti-hyperglycaemic and lipid lowering potential of Adenanthera pavonina Linn. in streptozotocin induced diabetic rats. Oriental Pharmacy and Experimental Medicine, 12, 197-203. https://doi.org/10.1007/s13596-012-0074-2

Pusat Data dan Sistem Informasi Pertanian (2016). Outlook Susu Komoditas Pertanian Subsektor Pertanian. Jakarta, Indonesia: Pusat Data dan Sistem Informasi Pertanian Sekretariat Jenderal Kementerian Pertanian Indonesia. [In Bahasa 
Indonesia].

Radziah, W., Najwa, M.R.M. and Nurfadilah, M.I. (2011). Basic study on antibacterial properties of Adenanthera pavonina (Saga) seed oil. IEEE Symposium on Business, Engineering and Industrial Applications (ISBEIA), Langkawi, 2011. Langkawi, Malaysia: IEEE. https://doi.org/10.1109/ ISBEIA.2011.6088886

Raeisi, A., Derhami, V.F., Hosseini, A. and Dehghani, S. (2017). Sensory evaluation and acceptability of soy yogurt with different grouping of treatments. Frontiers in Food and Nutrition Research, 3(1),1-6.

Savitry, N.I., Nurwantoro and Setiani, B.E. (2017). Total lactic acid bacteria, total acid, $\mathrm{pH}$ value, viscosity, and characteristic appearance of yoghurt with the addition of tomato fruit Juice Jurnal Aplikasi Teknologi Pangan, 6(4), 184-187.

Suita, E. (2013). Seri Teknologi Perbenihan Tanaman Hutan Saga Pohon (Adenanthera pavonina, L). Jakarta, Kementerian Kehutanan, Badan Penelitian Dan Pengembangan Kehutanan Balai Penelitian Teknologi Perbenihan Tanaman Hutan Indonesia. [In Bahasa Indonesia].

Wardhani, D.H., Maharani, D.C. and Prasetyo, E.A. (2015). Kajian pengaruh cara pembuatan susu jagung, rasio dan waktu fermentasi terhadap karakteristik yoghurt jagung manis. Momentum, 11 (1), 7-12. [In Bahasa Indonesia].

Winarno, F.G., Ahnan, W.W. and Widjajanto, W. (2003). Flora Usus dan Yogurt. Bogor, Indonesia: MBRIO. [In Bahasa Indonesia].

Yenrina, R., Fauzan, A., Dini, R. and Windasari, E.S. (2014). The Effect of addition of sesame (Sesamun indicum L.) filtrate towards the quality of tree saga bean (Adenanthefra pavonina, L.) milk. Pakistan Journal of Nutrition, 13(5), 275-280. https:// doi.org/10.3923/pjn.2014.275.280 